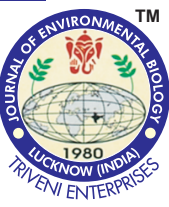

\title{
Characterisation of cholinesterase and histopathological features of brain of Clarias gariepinus following exposure to cadmium
}

\begin{tabular}{|c|c|}
\hline Paper received: 14.12.2017 & Revised received: 06.04.2018 \\
\hline
\end{tabular}

\section{Authors Info}

N.I. Fadzil', S.A. Ahmad", N.A. Yasid', M.K. Sabullah', H.M. Daud ${ }^{3}$, A. Khalid", S.N. Padrilah ${ }^{1}$ and M.Y. Shukor 'Department of Biochemistry, Faculty of Biotechnology and Biomolecular Sciences, Universiti Putra Malaysia, 43400 UPM Serdang, Selangor, Malaysia

${ }^{2}$ Faculty of Science and Natural Resources, Universiti Malaysia Sabah, Jalan UMS, 88400, Kota Kinabalu, Sabah, Malaysia

${ }^{3}$ Department of Veterinary Laboratory Diagnostic, Faculty of Veterinary Medicine, Universiti Putra Malaysia, 43400 UPM Serdang, Selangor, Malaysia

${ }^{4}$ Faculty of Health Sciences, Universiti Kebangsaan Malaysia, Jalan Raja Muda Abdul Aziz, 50300 Kuala Lumpur, Malaysia

*Corresponding Author Email : aqlima@upm.edu.my

\section{Edited by \\ Dr. Qtae Jo}

\section{Reviewed by}

Dr. Sambasiva Tilak

Dr. Vijay Mala Nair

\section{Abstract}

Aim : Cholinesterase (ChE) inhibition and histopathological features of brain tissues of Clarias gariepinus were investigated with a purpose to develop biomarkers for monitoring heavy metals.

Methodology : The effects of cadmium toxicity on C. gariepinus were assessed by $\mathrm{ChE}$ inhibition and characterisation of ChE by affinity chromatography and histological variations in brain tissues were studied by H\&E staining under light microscope.

Results : The purified enzyme gave 10.58 fold purification with the recovery of $12 \%$ with specific activity of $159.729 \mathrm{U}$ $\mathrm{mg}^{-1}$. The Michaelis-Menten constant $\left(\mathrm{K}_{\mathrm{m}}\right)$ and $V_{\max }$ value obtained was $1.985 \mathrm{mM}$ and $0.4479 \mu \mathrm{mol} \mathrm{min}^{-1} \mathrm{mg}^{-1}$, respectively. The enzyme showed the ability to hydrolyse acetylthiocholine iodide (ATC) at a faster rate compared to other two synthetic substrates, propionylcholine iodide (PTC) and butyrylthiocholine iodide (BTC). ChE showed highest activity at $35^{\circ} \mathrm{C}$ in $\mathrm{Tris}-\mathrm{HCl} \mathrm{pH} \mathrm{7.5.} \mathrm{The}$ metal inhibition study also found the maximal inhibitory concentration $\left(\mathrm{IC}_{50}\right)$ value for cadmium to be $0.6517 \mathrm{mg} \mathrm{l}^{-1}$. Histological study revealed decrease in the number of cells, degeneration of Purkinje cells, increased aggregation area and cells necrosis.

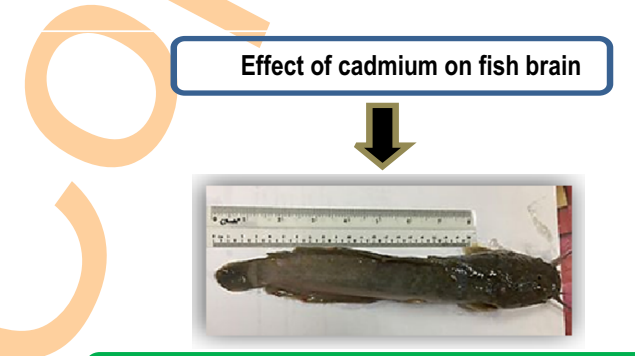

Clarias gariepinus brain as potential biomarker

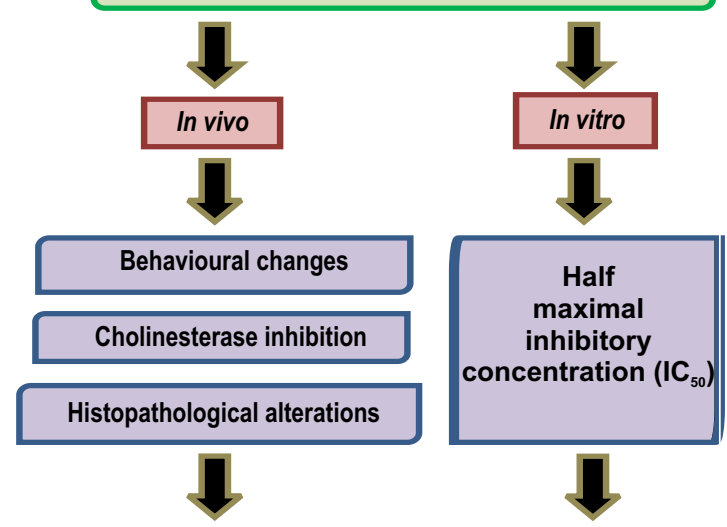

A biomarker tools can be developed for detecting cadmium toxicity in aquatic ecosystem
Interpretation : Inhibition of cholinesterase activity and degeneration of Purkinje cells observed in the present study can be used as a tool for further developing a biomarker for detecting heavy metals in the aquatic ecosystems.

Key words: Biomarker, Cadmium, Cholinesterase, Clarias gariepinus, Histopathology

How to cite: Fadzil, N.I., S.A. Ahmad, N.A. Yasid, M.K. Sabullah, H.M. Daud, A. Khalid, S.N. Padrilah and M.Y. Shukor: Characterisation of cholinesterase and histopathological features of brain of Clarias gariepinus following exposure to cadmium. J. Environ. Biol., 40, 133-142 (2019). 


\section{Introduction}

Clarias gariepinus (catfish) is considered as one of the most significant fish species. Globally, African catfish is commercially grown due to its popularity as a common fresh water fish that is widely consumed. It has been recorded as a commercially important fish being resistant to several diseases (Mdegela et al., 2010). They are particularly vulnerable and heavily exposed to aquatic pollution (Saleh and Marie, 2014). These organisms are often at the top of the aquatic food chain and may concentrate a large amount of metals from the surrounding waters (Rajkowska et al., 2011). As known, the concentration of heavy metals in the aquatic environment have increased dramatically due to industrial, mining, agricultural and domestic activities (Abbas et al., 2002). The metals gets bioaccumulated at different levels in various organs of aquatic organisms (Zaki et al., 2016). Cadmium is a common environmental metal contaminant, and dispersion of cadmium in the environment has increased over the past decades due to its extensive use in nickel-cadmium battery production and metal plating (Sharma et al., 2014). In general, cadmium is biologically non-essential, non-biodegradable, persistent type of heavy metal known to have high toxic potentials (Jaishankar et al., 2014).

Some of the physiological effects of chronic exposure to cadmium at sublethal levels are manifested in the form of disturbances in respiration, reduction in growth, changes in hematology and enzyme activity that reveal the stress response in fish (Lacroix and Hontela, 2004). A study conducted by Alsawafi et al. (2017) on zebra fish (Danio rerio) exposed to cadmium showed a significantly exponential increase over time and peaked at day 25 , plus obvious tissue chaos was noticed in the treated fishes compared to the control group. Rani et al. (2015) also reported cholinesterase enzyme activity as an early warning biomarker for the presence of cadmium pollution of Indian major carps.

Fish are also ideal sentinels for behavioural assays of toxic chemical exposure due to their constant and direct contact with the aquatic environment due to the chemical exposure occurs over the entire body surface and ecological relevance in many natural systems (Halappa and David, 2009). Most behavioural study in fish under toxic media are swimming performance which exhibit irregular, erratic and darting swimming movements, hyper excitability, and loss of equilibrium and sinking to the bottom (Sharbidre and Patode, 2012). The behavioural changes may be due to the inhibition of acetylcholinesterase (AChE) activity. This is because inactivation of AChE activity results in excess accumulation of acetylcholine (ACh) in cholinergic synapses leading to hyper stimulation and cessation of neuronal transmission (paralysis).

Catfish is a prime cultured and an important staple freshwater fish, generally found in rivers, ponds and reservoirs. Contamination of aquatic biota at sublethal levels by cadmium is common in Malaysia, mostly in Langat River (Shazili et al., 2006).
In view of this, the present study was undertaken to evaluate the behavioural responses, brain histology features and cholinesterase activity of $C$. gariepinus exposed to various concentrations of cadmium.

\section{Materials and Methods}

Fish sampling and treatment of $\mathrm{CdCl}_{2}$ : Healthy Clarias gariepinus weighing $100 \pm 20 \mathrm{~g}$ and $20 \pm 2 \mathrm{~cm}$ in length were bought from a commercial supplier in Semenyih, Selangor. They were brought to laboratory in well-aerated container to avoid physical injuries and stress to the fish. C. gariepinus were acclimatised under laboratory conditions for 5 to 10 days in a glass aquarium containing $40 \mathrm{I}$ of dechlorinated water. During this time, fish were fed with commercial fish pellet to sustain fish health. After acclimatisation, C. gariepinus was exposed to different concentrations of $\mathrm{CdCl}_{2}$ (1-50 $\left.\mathrm{mg} \mathrm{l}^{-1}\right)$ for $96 \mathrm{hrs}$, based on the study conducted by Okareh and Akande (2015) with $\mathrm{LC}_{50}$ value of $16.3 \mathrm{mg} \mathrm{l}^{-1}$.

Physiological and behavioural study: Behavioural responses, clinical signs and mortality rates were recorded. Behavioural pattern such as swimming, fin movement and food intake by fish were monitored. After $96 \mathrm{hrs}$ of treatment, the number of dead fish in each group was recorded, and the remaining fish were removed from the aquarium, placed in an ice bath, and then sacrificed by decapitation.

Histopathological study: The brain tissue of fish were dissected and fixed in $10 \%$ neutral buffer formalin. The samples were then subjected to dehydration before being embedded in wax. $\mathrm{A} 5 \mu \mathrm{M}$ thick sections of brain were cut and stained in hematoxylin-eosin. The stained sections were observed under microscope.

Preparation of crude homogenate: C. gariepinus was freezekilled by immersing the fish in ice for about $30 \mathrm{~min}$. The brain was removed and weighed for homogenising process. The brain collected was homogenised in $0.1 \mathrm{M}$ sodium phosphate buffer (pH 7) containing $2 \mathrm{mM}$ phenylmethylsulfonyl fluorides with the sample and buffer in 1:4 (w/v) ratio. Homogenisation was carried out using Ultra-Turrax T25 Homogenizer. Homogenate was then centrifuged at 10,000 $\mathrm{xg}$ in a Sorvall Ultra Pro-TH-641 centrifuge for 20 min at $4^{\circ} \mathrm{C}$ (Sabullah et al., 2015a). The supernatant was collected and stored at $-25^{\circ} \mathrm{C}$ in clean polycarbonate tubes.

Determination of cholinesterase (ChE) activity: The ChE activity of $C$. gariepinus was estimated following the method of Ellman et al. (1961) with slight modification. The enzyme assay was carried out by adding $10 \mu \mathrm{l}$ crude sample into 96-well microplate containing $200 \mu$ of sodium phosphate buffer $(0.1 \mathrm{M}$, $\mathrm{pH} 7.0)$ and $20 \mu \mathrm{l}$ of 5, 5'-dithiobiss (2-nitrobenzoic acid) (0.1 M). The sample was then incubated for 15 min before $20 \mu \mathrm{l}$ substrates $(5.0 \mathrm{mM}$ acetylthiocholine iodide, butyrylthiocholine iodide and propionylthiocholine iodide) was added into the mixture and incubated for another $10 \mathrm{~min}$ to allow for the reaction to occur. ChE activity was expressed as the amount of substrate $(\mathrm{mM})$ broken down by ChE per min (U) with the 
extinction coefficient of $13.6 \mathrm{mM}^{-1} \mathrm{~cm}^{-1}$ and the specific activity was expressed as $\mu$ mole $\mathrm{min}^{-1} \mathrm{mg}^{-1}$ of protein or $\mathrm{U} \mathrm{mg}{ }^{-1}$ of protein (Ellman et al., 1961). Protein content was determined by to the method of Bradford, taking bovine serum albumin as standard (Bradford et al., 1976).

Purification of ChE through affinity chromatoghraphy and SDS-PAGE : The purification process was carried out by affinity chromatography, which is routinely used to purify $\mathrm{ChE}$ from several sources. Partial purification of the enzyme was carried out. Procainamide-Sephacryl $6 \mathrm{~B}$ resin was packed into a column with dimension of $16 \mathrm{~mm}$ diameter and $50 \mathrm{~mm}$ height using $20 \mathrm{mM}$ sodium phosphate buffer at $\mathrm{pH} 7.0$ prior to loading the brain extract of $C$. gariepinus. The resin was prepared based on the method of Hodgson and Chubb (1983) with slight modification. The crude brain extract $(240 \mu \mathrm{l})$ was loaded into the column. Washing was done by passing $10 \mathrm{ml}$ of washing buffer $(20 \mathrm{mM}$ sodium phosphate buffer, pH 7.0) into the column at a flow rate of $1 \mathrm{ml} \mathrm{min}^{-1}$. The elution process was then carried out using $20 \mathrm{mM}$ sodium phosphate buffer (pH 7.0) containing 1.0 M sodium chloride. Sodium dodecyl sulfate polyacrylamide gel electrophoresis (SDS-PAGE) was performed according to the procedure described by Laemmli (1970) for monitoring purification. The polyacrylamide gel was set up using combination of stacking gel (4\%) and resolving gel (12\%).

Effect of temperature, $\mathrm{pH}$ and substrate on enzyme activity : Purified ChE activity was tested by incubating enzyme with three synthetic substrates viz., acetylthiocholine iodide (ATC), butyrylthiocholine iodide (BTC) and propionylthiocholineiodide (PTC) at $0.1 \mathrm{M}(\mathrm{pH} 7.0)$ and different concentrations of substrate $(0.1,0.5,1,2$ and $2.5 \mathrm{mM})$. Maximum velocity $\left(\mathrm{V}_{\max }\right)$ and Michaelis-Menten constant $\left(\mathrm{K}_{\mathrm{m}}\right)$ values were determined using Graphpad Prism 5.0. The effect of $\mathrm{pH}$ was elucidated by equilibrating purified AChE for 15 min with different buffers and different $\mathrm{pH}$ conditions namely $0.1 \mathrm{M}$ each of acetate buffer $(\mathrm{pH}$ 3.0, 4.0, 5.0, and 5.5), sodium phosphate buffer ( $\mathrm{pH} 5.0,6.0,7.0$, 7.5 and 8.0) and Tris-HCl buffer (pH 7.0, 7.5 and 8.0). The effect of temperature was determined by incubating the assay mixture at $15,20,25,30,35,40$ and $50^{\circ} \mathrm{C}$ for $15 \mathrm{~min}$.

Half maximal inhibitory concentration $\left(I C_{50}\right)$ : The half maximal inhibitory concentration $\left(\mathrm{IC}_{50}\right)$ served as the sensitivity coefficient of fish to inhibitors. $I C_{50}$ study of partially purified ChE activity from C. gariepinus was conducted using different concentrations of $\mathrm{Cd}$ ranging from 1.0 to $10.0 \mathrm{mg} \mathrm{l}^{-1}$. The heavy metal inhibition profile of ChE activity was analysed and the $\mathrm{IC}_{50}$ value of heavy metal was obtained using GraphPad Prism to access in vitro effect of cadmium.

\section{Results and Discussion}

Fish behavior represents the fish physiological response towards the environmental factor (Sabullah et al., 2015b). Alteration in behavior is considered as a sensitive biomarker to evaluate the toxic exposure and effect of status of fish body (Gerhardt, 2007). The parameter for behaviour alteration measurement such as swimming performance, avoidance behavior and feed intake was studied during a $96 \mathrm{hrs}$ treatment with cadmium. The swimming behaviour exhibited a decrease in swimming as cadmium concentrations were increased, and the started fish to swim to the water surface together with increased frequency of opercula and mouth movement indicating difficulty in breathing. This proved that cadmium toxicity caused loss of resistance in swimming performance of the fish.

Eissa et al. (2006) reported that $\mathrm{Cd}^{2+}$ caused changes in the spatial distribution of Cyprinus carpio, which reflected as alterations in the preferred swimming depth when exposed to sublethal concentration of cadmium. Meanwhile, Padrilah et al. (2017) reported vertical and downward swimming patterns and sudden movements of $C$. gariepinus exposed to low concentration of copper; the fish began to sink to the bottom and became motionless at high concentration $\left(10.0,15.0\right.$ and $\left.20.0 \mathrm{mg} \mathrm{l}^{-1}\right)$. Meanwhle, in the control group there were no behavioural changes, and no mortality was recorded throughout the experiment. The abnormal swimming pattern of $C$. gariepinus under stressful conditions may be due to the obstructed functions of neurotransmitters, which may have disrupted the nervous system (Adakole, 2012).

Swimming performance was found to affect the appetite in fish groups exposed to increasing concentrations of cadmium which may be due to the inhibition of dopamine and serotonin involved in locomotion, aggression and feeding behaviour, in the presence of heavy metals. Study on the role of some feed additives in fish fed on diets contaminated with cadmium also showed that daily feed intake decreased significantly $(p<0.001)$ with increasing dietary cadmium level Ayyat et al. (2017).

The general histological screening indicated a low to high cadmium damage on brain tissue of C. gariepinus after $96 \mathrm{hrs}$. Histopathological alterations observed in the brain tissue is shown in Fig. 1. The control group did not show any histological changes in any of the tissues examined (Fig. 1A) and constituted of normal neuronal cell, pyramidal cell and nissl substances. In contrast, exposure to $5 \mathrm{mg} \mathrm{l}^{-1} \mathrm{Cd}$ (Fig. 1B) showed neuronal cell degeneration, dystrophic changes, swelling of pyramidal cells, loss of nissl substances and vacuolisation. Dark-stained degenerating neurons and vacuolar changes with empty spaces, which appeared as moth-eaten area, increased in number at 10 $\mathrm{mg} \mathrm{l}^{-1} \mathrm{Cd}$ exposure (Fig. 1C). Cerebral edema started appearing due to alteration in brain cell. Exposure to $30 \mathrm{mg} \mathrm{l}^{-1} \mathrm{Cd}$ (Fig. 1D), increased in the formation of neuronal cell degeneration, vacuolisation and cerebral edema. The cell was totally damaged, and the formation of generalised cell edema and cell vacuolization increased (Fig. $1 \mathrm{E}$ ) at $50 \mathrm{mg} \mathrm{l}^{-1} \mathrm{Cd}$ exposure.

$\mathrm{Cd}$ is a persistent neurotoxic contaminant that can cause behavioural changes, impairing the subsequent survival or reproduction of the exposed organisms (Beauvais et al., 2001). In the present study, $\mathrm{Cd}$ treated fish group revealed neuronal cell degeneration and swelling of pyramidal cells (Fig. 1B), which 

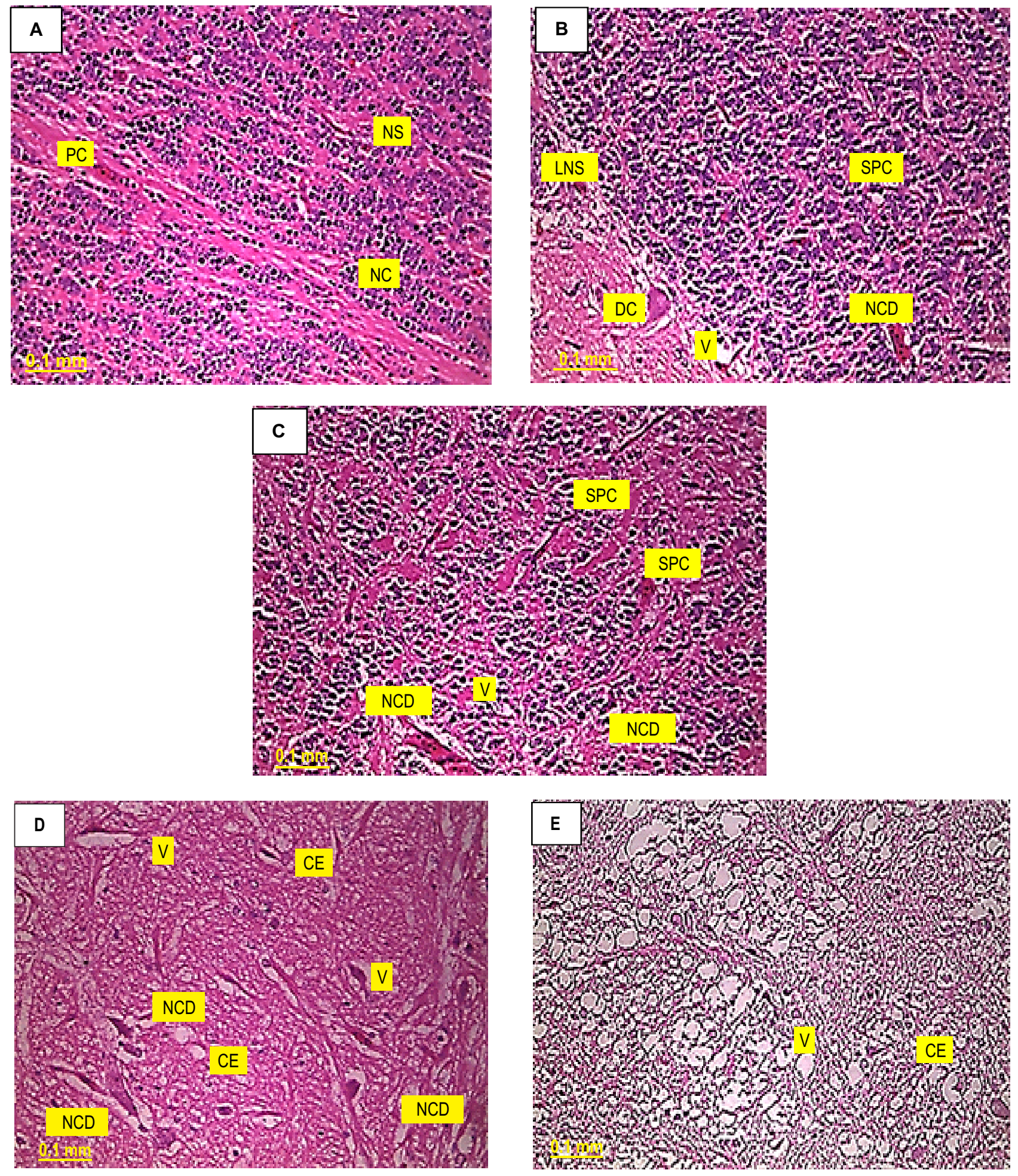

Fig. 1: Characteristic histopathological changes in the brain of Clarias gariepinus revealed by H\&E staining (400X) after 96 hrs treatment: A) Control. Pictomicrograph of brain tissue of $C$. gariepinus showing pyramidal cell (PC), neuronal cell (NC) and Nissls substances (NS); (B) Treated with $5 \mathrm{mg} \mathrm{I}^{-1}$ cadmium showing loss of Nissl, substance (LNS), dystrophic changes (DC), vacuolisation (V), neuronal cells degeneration (NCD) and swelling of pyramidal cells (SPC); (C) Treated with $10 \mathrm{mg} \mathrm{l}^{-1}$ of cadmium showing neuronal cells degeneration (NCD), vacuolisation (V) and swelling of pyramidal cells (SPC); (D) Treated with $30 \mathrm{mgl}^{-1}$ cadmium showing neuronal cells degeneration, vacuolisation and cerebral edema (CE) and (E) Treated with $50 \mathrm{mg}$ $\Gamma^{-1}$ cadmium showing increased vacuolisation and cerebral edema. 


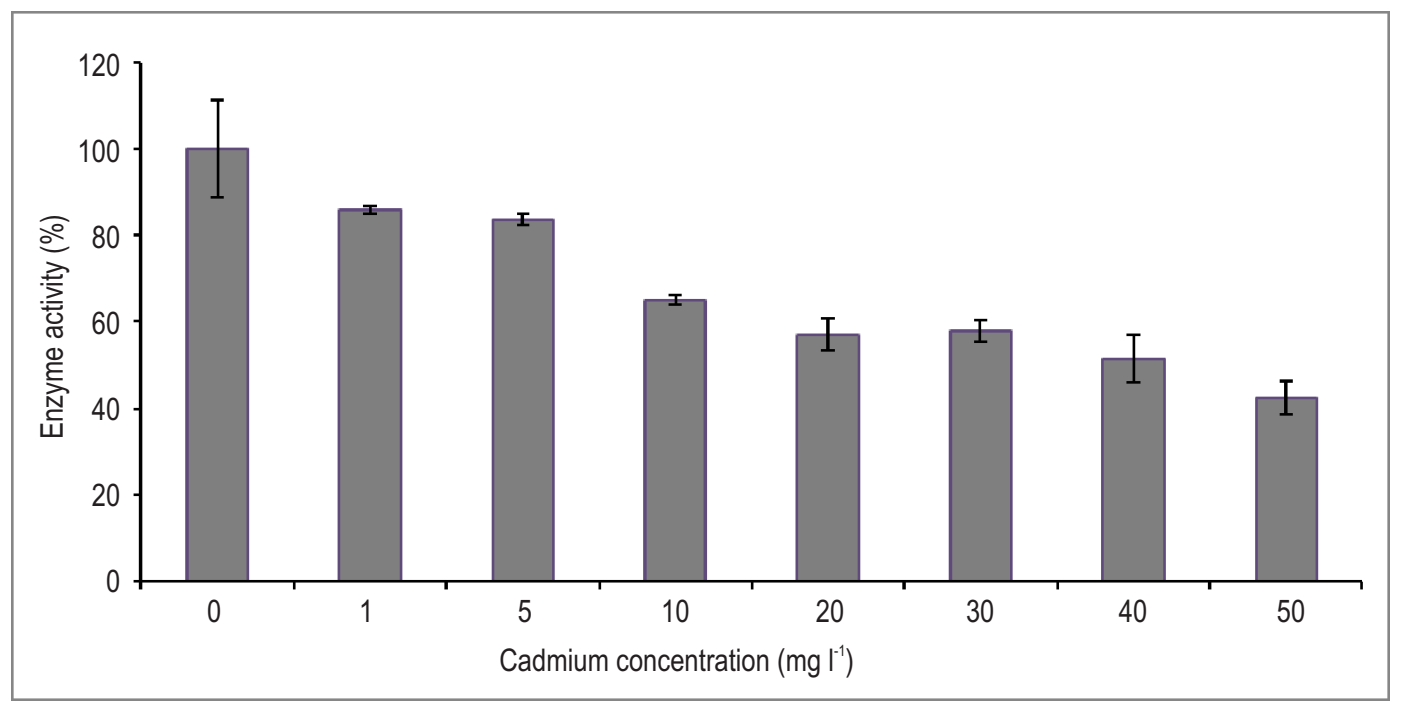

Fig. 2 : Percent inhibition of cholinesterase in the brain extract of Clarias gariepinus exposed for 96 hrs. Error bars representmean $\pm S E(n=3)$.

corroborates with the previous study of Patnaik et al. (2011) on Cyprinus carpio communis exposed to sublethal concentration of Cd (4.3 and $1.6 \mathrm{ppm})$. The incidence of severe necrosis by neuronal cells degeneration indicates loss of nissl granules in cerebrum and mild vacuolar changes (Loganathan et al., 2006) in Lobeo rohita exposed to $10 \mathrm{ppm}$ of Zn and Catla catla exposed to copper and iron (Bose et al., 2003). Vacuolisation in brain tissue may be due to glycolysis leading to microsomal and mitochondrial dysfunction (Ramudu and Dash, 2015), which can be observed clearly in Fig. 1C. Similar results were reported by Babatunde et al. (2015) on Oreochromis niloticus brain exposed to $2 \mathrm{mg} \mathrm{l}^{-1}$ paraquat for 10 weeks. Severe cerebral edema exhibited in the present study (Fig. 1D) indicates $\mathrm{Cd}$ toxicity that has also been implicated on increasing the permeability of blood brain barrier leading to cerebral edema (Wang and Du, 2013; Gonçalves et al., 2010).

Total ChE activity was determined to study the activity of enzymes from the brain extract of $C$. gariepinus using three different types of substrate : Acetylthiocholine iodide, Butyrylthiocholine iodide and Propionylthiocholine iodide. Present study showed ATC with highest significant enzyme

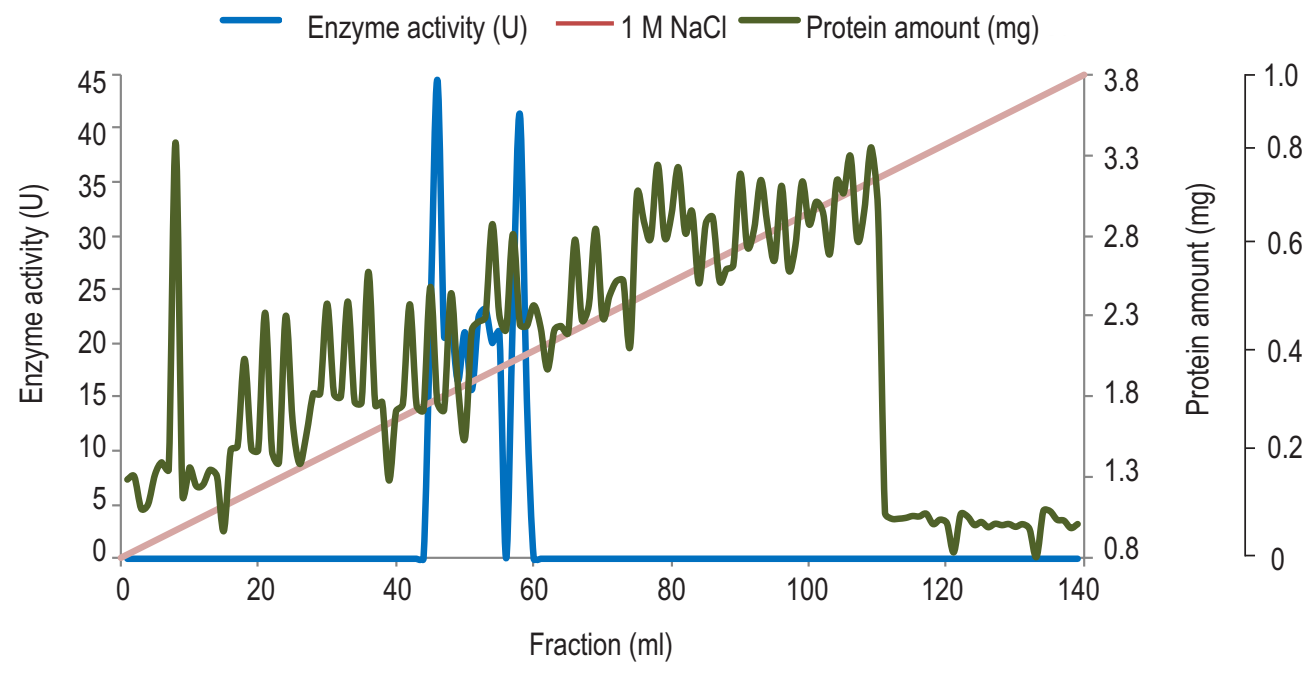

Fig. 3 : Elution profile of partially purified acetylcholinesterase from the brain extract of Clarias gariepinus using Procainamide-Sephacryl 6B affinity chromatography method. 


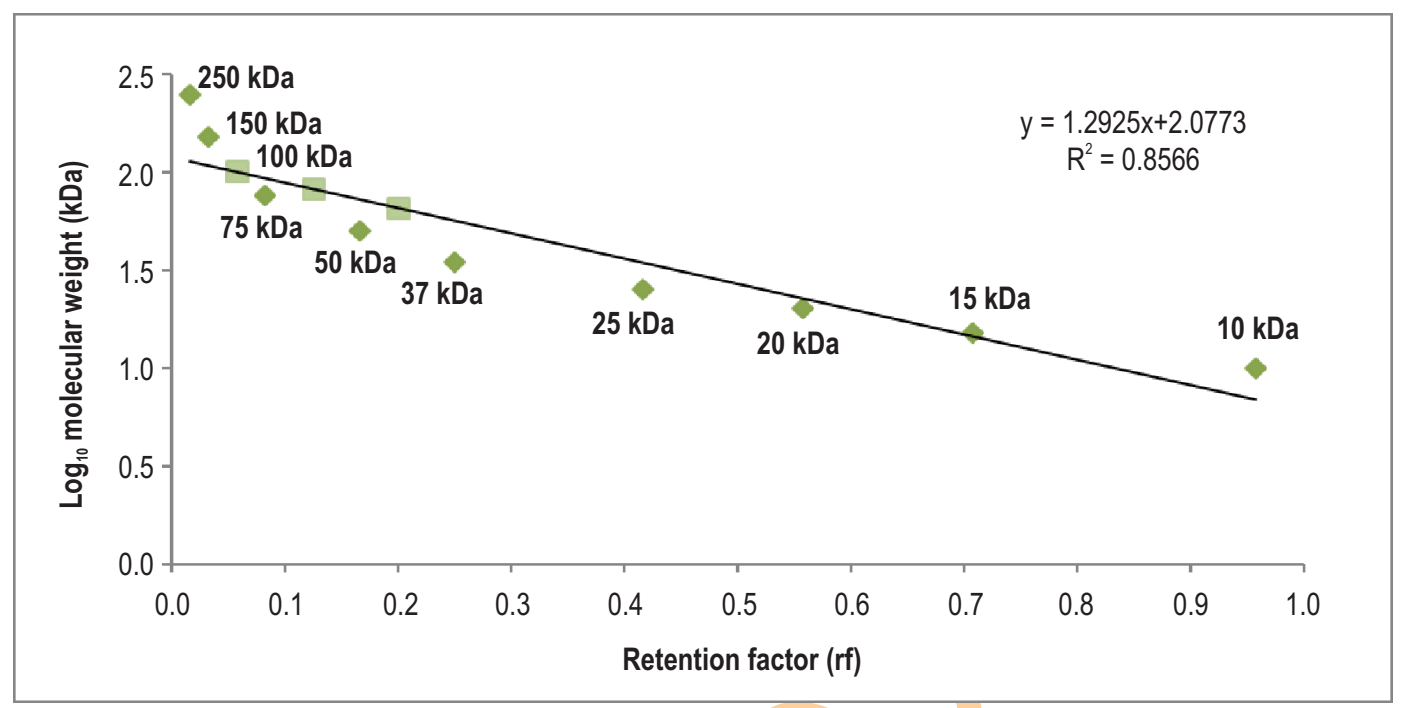

Fig. 4 : Molecular weight of purified cholinesterase from Clarias gariepinus by interpolation of retention factor (rf) of protein markers. Purified ChE indicated by green dotted.

activity $(\mathrm{p}<0.05)$ with a total ChE activity of $31.0938 \mathrm{U}$ compared to other two substrates; BTC (9.97549 U) and PTC (19.74265 U). High ChE activity in ATC was probably due to its biochemical role in the brain. AChE is abundant in the brain, and its main function is to regulate cholinergic neurotransmission by catalysing the hydrolysis of acetylcholine at neuromuscular junction and central synapses (Rodrigues et al., 2011). Supported by Ferrari et al. (2007), AChE accounts for more than $97 \%$ of the total brain cholinesterases in most teleosts. Nunes (2011) also claimed that the major cholinesterasic form in the brain tissues of Dicentrarchus labrax is AChE.

The results obtained from the substrate profile is also in agreement with the study conducted by Ding et al. (2011), where they extracted the brain ChE from Oreochromis aurea that showed specific affinity towards ATC as its substrate. Thus, the highest ChE activity for ATC was used for subsequent purification. The in vivo study of $\mathrm{ChE}$ inhibition by $\mathrm{Cd}$ is shown in Fig. 2 where higher concentrations of $\mathrm{Cd}$ inhibited ChE activity from C. gariepinus brain exposed to $\mathrm{Cd}\left(1-50 \mathrm{mg} \mathrm{l}^{-1}\right)$, likely due to the bioaccumulation of $\mathrm{Cd}$ in fish affecting enzyme directly by binding to catalytic functional group in enzyme, and also the ability of $\mathrm{Cd}$ to bind with lipid-rich structures of mitochondria (Rani et al., 2015).

Fig. 3 shows the purification data of C. gariepinus ChE from the procainamide-based affinity chromatography. A significant amount of protein and a low ChE activity were detected at the washing stage probably due to column overloading. ChE was isolated at the eluting stage of purification with high ionic strength $20 \mathrm{mM}$ of sodium phosphate buffer $\mathrm{pH} 7.5$, containing $1.0 \mathrm{M} \mathrm{NaCl}$ (fractions 46-58). Fractions with the highest $\mathrm{ChE}$ activity were pooled together for the next step of enzyme characterisation. The affinity purification on Procainamide-Sephacryl 6B matrix resulted in ChE purification fold of 10.58 times relative to the specific activity of crude extract and with $12 \%$ recovery. Affinity chromatography was found to be the most preferred method as it uses specific binding properties. It has a specific ligand, procainamide for ChE to bind. The enzyme activity was observed to decrease throughout the purification process. A decrease in enzyme activity is probably due to the denaturation of $\mathrm{ChE}$ and unavoidable loss of ChE during purification (Dako et al., 2012).

Purification of ChE using Procainamide-Sephacryl 6B as matrix in affinity chromatography aided to exclude the undesired proteins and retention of only desired protein, i.e., ChE. Based on the SDS-PAGE gel profile, the molecular weights of the unknown protein bands, after partial purification through affinity chromatography, appeared within the range of 100 to $37 \mathrm{kDa}$. Three bands were observed and the molecular weight of each unknown protein band was calculated using the calibrated protein marker standard curve (Fig. 4). The diamond bullets indicate the position of protein bands from the partially purified AChE fraction. Fish AChE usually has a molecular weight of about $60 \mathrm{kDa}$ (Tripathi and Srivastava, 2008). For example, ChE from Colossoma macropomum has a size of $62 \mathrm{kDa}$ (Silva et al., 2015), however, Assis et al. (2015) reported a molecular weight of $220 \mathrm{kDa}$ for AChE extracted from the fish, Arapaima gigas. The results of SDSPAGE in this study showed a probable molecular weight of AChE that brackets the $60 \mathrm{kDa}$ theoretical molecular weight of AChE from fish; however, further purification is needed to correctly assess the molecular weight of AChE from $C$. gariepinus. Although a single band was not obtained from the experiment, the presence of $\mathrm{ChE}$ was verified by enzyme assay. Protein analysis through SDS-PAGE helps to elucidate the 
(A)

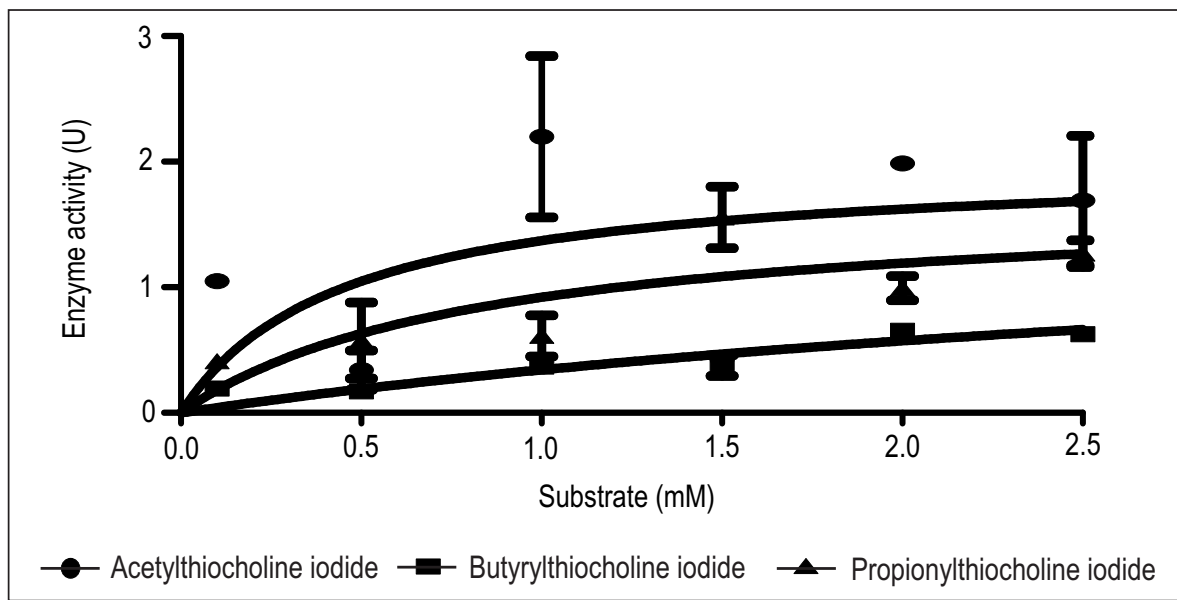

(B)

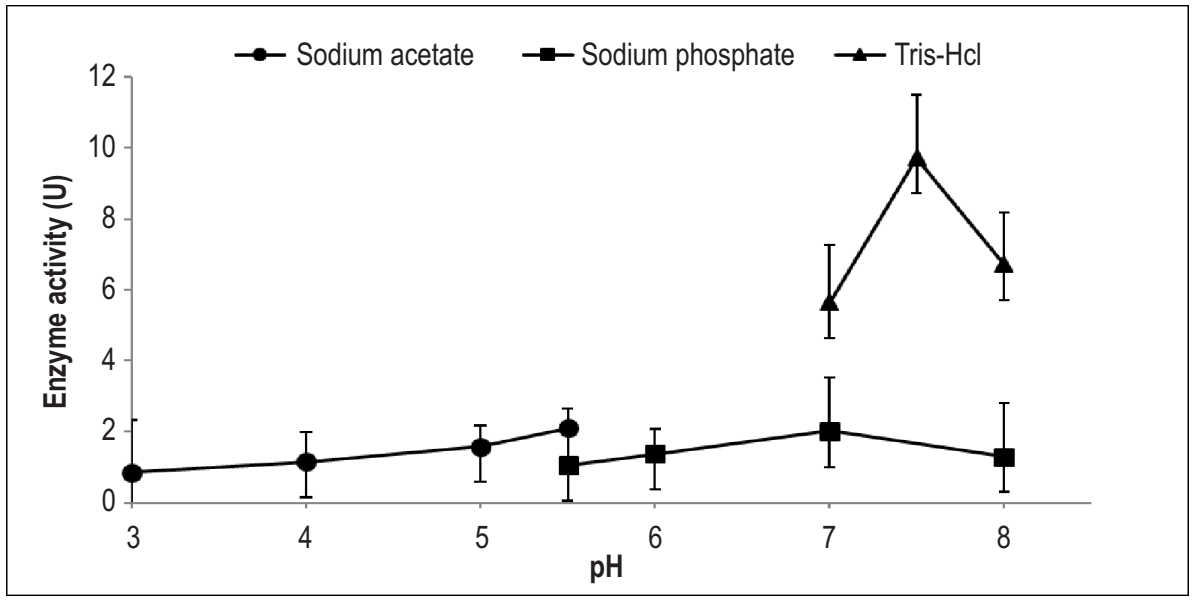

(C)

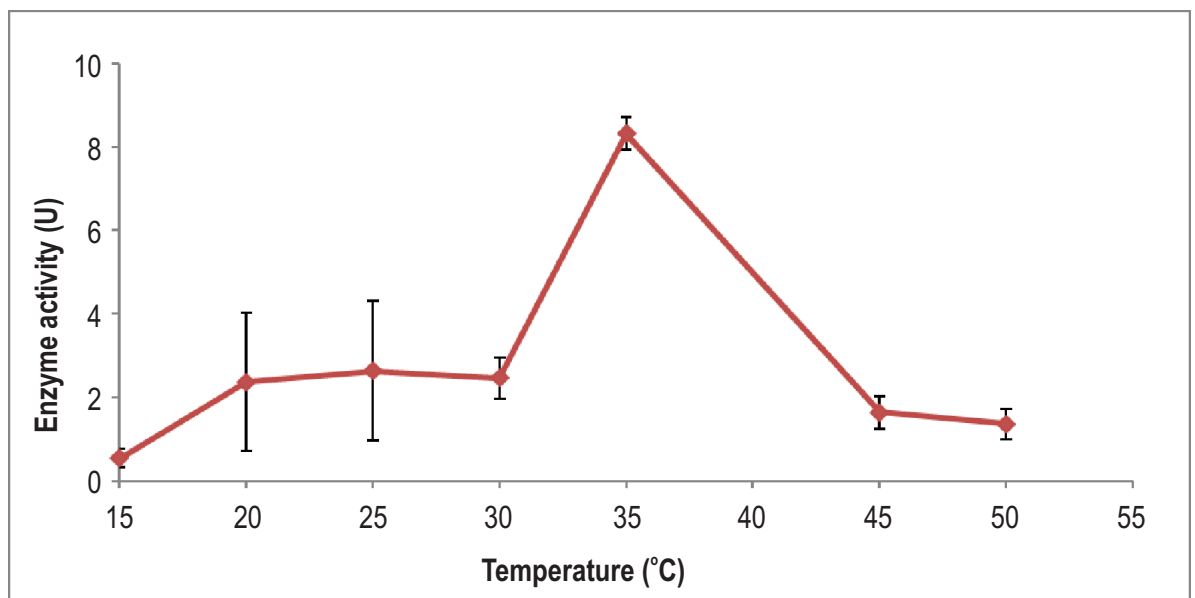

Fig. 5: Effects of (A) substrate specificity profile of three synthetic substrates, (B) pH and (C) temperature on the enzyme activity of partially purified AChE from the brain extract of $C$. gariepinus. Error bars indicate mean of three replicates $\pm S E(n=3)$. 


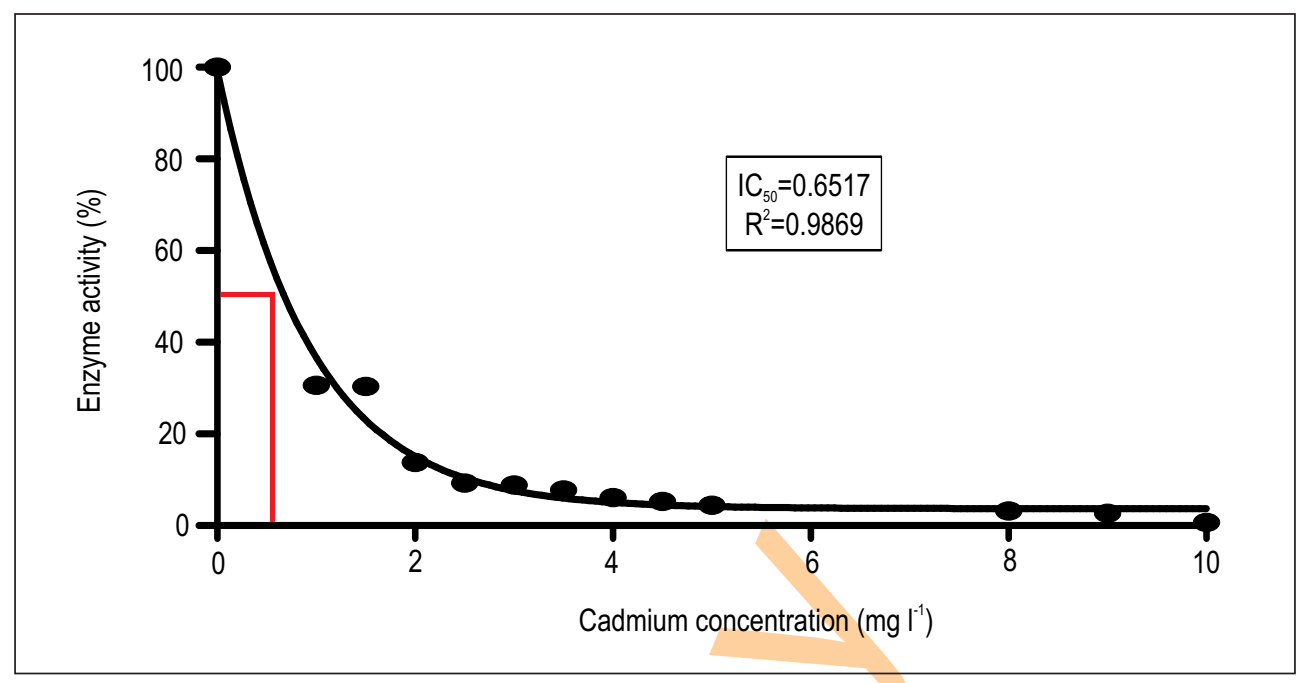

Fig. 6 : Percent inhibition on the enzyme activity of partially purified acetylcholinesterase from the brain extract of Clarias gariepinus.

effectiveness of purification on AChE from the brain extract of $C$. gariepinus.

The rate of enzymatic hydrolysis of ATC, BTC and PTC increased from 0 to $2.5 \mathrm{mM}$, thus proving the potential of enzyme to hydrolyse substrates at different frequencies (Fig. 5A). All the substrates showed significant difference in term of catalytic reaction $(p<0.05)$. Purified ChE also showed the potential to hydrolyse ATC with highest rate as compared to BTC and PTC with maximal velocity $\left(\mathrm{V}_{\max }\right)$ reaching to $1.985 \mu \mathrm{mol} \mathrm{min}^{-1} \mathrm{mg}^{-1}$ and substrate affinity based on the apparent biomolecular constant, $\mathrm{K}_{\mathrm{m}}$ value of 0.4479 . The $\mathrm{V}_{\max } / \mathrm{K}_{\mathrm{m}}$ ratio showed catalytic efficiency towards purified sample. In the present study, ATC showed highest $\mathrm{V}_{\text {max }} / \mathrm{K}_{\mathrm{m}}$ ratio of 4.4318 among the substrates. AChE is abundant in brain tissue contain abundance of AChE (Tsim and Soreq, 2012). Thus, AChE hydrolyses ATC more efficiently than other substrates. Therefore, ATC with a concentration of $2.5 \mathrm{mM}$ was selected as the preferred substrate for further analysis. Fig. $5 \mathrm{~B}$ shows the influence of $\mathrm{pH}$ on the enzyme activity by using different buffer.

The figure indicates that the enzyme activity was relatively low at $\mathrm{pH} 3$ and increased to $\mathrm{pH} 5.5$ in sodium acetate buffer. Enzyme activity also showed similar results under sodium phosphate buffer at $\mathrm{pH} 5.5$ and increased at $\mathrm{pH} 7$, with a sharp increase in the enzyme activity beyond $\mathrm{pH} 7$ to 7.5 in Tris$\mathrm{HCl}$ buffer and decreased at $\mathrm{pH} 8$. The result showed that $\mathrm{AChE}$ activity in $\mathrm{C}$. gariepinus has a broad $\mathrm{pH}$ range and $\mathrm{pH} 7.5$ was selected as optimum $\mathrm{pH}$ as mean point was highest among others. At this point, the neutralisation of imidazole group in the AChE structure led to the stabilisation of the enzyme-substrate complexes. It is also an ideal state for AChE to hydrolyse its substrate. Optimum condition near to neutral $\mathrm{pH}$ from other sources of AChE has been reported (Ding, 2011). The result was similar to a study conducted by Hayat et al. (2016), where the maximum ChE activity in freshwater fish, Lates calcifier was observed between $\mathrm{pH} 7.0$ and 8.0 with equal activity using either potassium phosphate or Tris-HCl buffers. Tris-HCl buffer was selected as the best buffering system for the characterisation of AChE. The result can also be compared with that of AChE assessment from Toman (Channa micropeltes), where its partially purified AChE displayed the highest activity on ATC using 0.1 M Tris-HCl buffer at pH 7 (Sharif et al., 2014). Thus, Tris- $\mathrm{HCl}$ with $\mathrm{pH} 7.5$ was used as optimum buffer for further analysis of AChE activity.

Fig. $5 \mathrm{C}$ shows that the activity of purified $\mathrm{AChE}$ increased until it reached an optimal temperature of $35^{\circ} \mathrm{C}$ due to increase in the kinetic energy between AChE and its substrate that further increased AChE activity, hence driving the high rate of collision between molecules (Ahmad et al., 2016). The result of high enzyme activity leads to the efficient formation of enzymesubstrate complexes and the increase in the amount of products. Moreover, similar reports were elucidated by Sabullah et al. (2014) and Assis et al. (2015) where optimum temperature for AChE was $35^{\circ} \mathrm{C}$ in Rachycentron canadum and Puntius javanicus. Beyond $50^{\circ} \mathrm{CAChE}$ activity was completely lost.

Screening of heavy metals showed that brain AChE of C. gariepinus was sensitive towards $\mathrm{Cd}$ as it inhibited the enzyme activity, greater than $50 \%$. The $\mathrm{IC}_{50}$ value of partially purified AChE activity was determined to be $0.6517 \mathrm{mg} \mathrm{l}^{-1}$ (Fig. 6). Sarkarati et al. (1999) reported that the inhibition of ChE by metal ions is due to the attraction of negative charge of amino acid side chains that contain carboxyl groups, such as glutamate and aspartate present at the catalytic triad of $\mathrm{ChE}$, leading to structural change of the active site. Recently, Hayat et al. (2017) also reported that metal ions inhibition is caused by the affinity binding towards the amino acid side chain. Thus, it is suggested that the partially purified AChE from the brain extract 
of $C$. gariepinus has a potential to inhibit the activity of metal cons, and can act as a biomarker for monitoring other contaminants, such as pesticides.

\section{Acknowledgments}

This project was supported by funding received from The Ministry of Science, Technology and Innovation (MOSTI), Malaysia, under FRGS Grant no. 02-02-13-1256FR (FRGS/2/2013/ SG05/ UPM/ 02/16), ScienceFund MOSTI (02-01-04-SF0445) and PutraIPS grants $(9481400,9534700,9571700$ and 9600600$)$. We also thank Universiti Putra Malaysia for providing a GRF scholarship to Miss Nadia Izati Fadzil.

\section{References}

Abbas, H.H., K.H. Zaghloul and M.A. Mousa: Effect of some heavy metals pollutants on some biological and histopathological changes in the blue tilapia Oreochromis aureus. Egypt J. Agric. Res., 80, 1395-411 (2002).

Adakole, J.A.: Changes in some haematological parameters of the African catfish (Clarias gariepinus) exposed to a metal finishing company effluent. Indian J. Sci. Technol., 5, 2510-2514 (2012).

Ahmad, S.A., M.K. Sabullah, A.A. Basirun, A. Khalid, N.U. Yasid, I.M lqbal, N.A. Shamaan, M.A. Syed and M.Y. Shukor: Evaluation of cholinesterase from the muscle and blood of Anabas testudineus as detection of metal ions. Fresenius Environ. Bull., 25, 4253-4260 (2016).

Al-sawafi, A.G.A., L. Wang and Y. Yan: Cadmium accumulation and its histological effect on brain and skeletal muscle of Zebra fish. $J$. Heavy Met. Toxi., 2, 1 (2017)

Assis, C.R.D., A.G. Linhares, V.M. Oliveira, R.C.P. França, J.F. Santos, E.V.M.M. Carvalho, R.S. Bezerra and L.B. Carvalho: Effect of ions on the activity of brain acetylcholinesterase from tropical fish. $J$. Coastal Life Medi., 7, 505-514 (2015).

Ayyat, M.S., H.K. Mahmoud, A.E.M. El-Hais and K.M.A. El-Latif: The role of some feed additives in fish fed on diets contaminated with cadmium. Environ. Sci. Pollut. Res., 24, 23636-23645 (2017).

Babatunde, M.M., A.A. Oladimeji and A.H. Rafindadi: Histopathological changes in the gills, livers and brains of Oreochromis niloticus (TREWAVAS) exposed to paraquat in chronic bioassay. Int. J. Sci. Appl. Technol., 5, 2224-3577 (2015).

Beauvais, S.L., S.B. Jones, J.T. Parris, S.K. Brewer and E. Little: Cholinergic and behavioral neurotoxicity of carbaryl and cadmium to larval rainbow trout (Oncorhynchus mykiss). Ecotoxicol. Environ. Saf., 49, 84-90 (2001).

Bose, M.T.J., M. llavazhahan, R. Tamilselvl and M. Viswanathan: Effect of heavy metals on the histopathology of gills and brain of fresh water fish Catla catla. Biomed. Pharmacol. J., 6, 99-105 (2013).

Bradford, M.M.: A rapid and sensitive method for the quantitation of microgram quantities of protein utilizing the principle of protein dye binding. Anal. Biochem., 72, 248-254 (1976).

Dako, E., A.M. Bernier, A.T. Dadie and C.K. Jankowski: The problems associated with enzyme purification, chemical biology (Ed.: Prof. Deniz Ekinci). ISBN: 978-953-51-0049-2, InTech (2012).

Ding, Y.H., X.M. Wu and J.B. Fang: Purification and characterization of acetylcholinesterase from brain tissues of Oreochromis aurea and its application in environmental pesticide monitoring. Sci. Cold. Arid Reg., 3, 339-343 (2011).

Eissa, B.L., A. Salibián and L. Ferrari: Behavioral alterations in juvenile Cyprinus carpio (Linnaeus, 1758) exposed to sublethal waterborne cadmium. Bull. Environ. Contam. Toxicol. 77, 931-937 (2006).

Ellman, G.L., K.D. Courtney, J.V. Andres and R.M. Featherstone: A new and rapid colorimetric determination of acetylcholinesterase activity. Biochem. Pharmacol., 7, 88-95 (1961).

Ferrari, A., A. Venturino and A. Pechen de D'Angelo: Muscular and brain cholinesterase sensitivities to azinphosmethyl and carbaryl in the juvenile rainbow trout Oncorhynchus mykiss. Comp. Biochem. Physiol., Part C: Toxicol. Pharmacol., 146, 308-313 (2007).

Gerhardt, A.: Aquatic behavioral ecotoxicology: Prospects and limitations. Human Ecol. RiskAssess., 13, 481-491 (2007).

Gonçalves, J.F., A.M. Fiorenza and R.M. Spanevello: N-acetylcysteine prevents memory deficits, the decrease in acetylcholinesterase activity and oxidative stress in rats exposed to cadmium. Chem. Biol. Interact., 186, 53-60 (2010).

Halappa, R. and M. David: Behavioural responses of the freshwater fish, Cyprinus carpio (Linnaeus) following sublethal exposure to chlorpyrifos. Turk. J. Fish Aquat. Sci., 9, 233-238 (2009).

Hayat, N.M., N.A. Shamaan, M.Y. Shukor, M.K. Sabullah, M.A. Syed, A. Khalid, F.A. Dahalan and S.A. Ahmad: The use of Lates calcarifer as a biomarker for heavy metals detection. Rend. Lincei Sci. Fis. 27, 463-472(2016).

Hayat, N.M., S.A. Ahmad, N.A. Shamaan, M.K. Sabullah, M.Y. Abd Shukor, M.A. Syed, A. Khalid, K.A. Khalil and F.A. Dahalan: Characterisation of cholinesterase from kidney tissue of Asian Sea bass (Lates calcarifer) and its inhibition in presence of metal ions. J. Environ. Biol., 38, 383-388 (2017).

Hodgson, A.J. and W. Chubb: A method for the detection and quantification of secretory acetylcholinesterase. Neurochem. Patho., 1, 211-218(1983)

Jaishankar, M., T. Tseten, N. Anbalagan, B.B. Mathew and K.N. Beeregowda: Toxicity mechanism and health effects of some heavy metals. Interdiscip. Toxicol., 7, 60-72 (2014).

Lacroix, A. and A. Hontela: A comparative assessment of the adrenotoxic effects of cadmium in two teleost species, rainbow trout, Oncorhynchus mykiss and yellow perch, Perca flavescens. Aquat. Toxicol., 67,13-21 (2004).

Laemmli, U.K.: Cleavage of structural proteins during the assembly of the head bacteriophage T4. Nature, 227, 680-685 (1970).

Loganathan, K., B. Velmurugan, J.H. Howrelia, M. Selvanayagam and B.B. Patnaik: Zinc induced histological changes in brain and liver of Labeo rohita (Ham.). J. Environ. Biol., 27, 107-110 (2006).

Mdegela, R.H., R.D. Mosha, M. Sandvik and J.U. Skaare:Assessment of acetylcholinesterase activity in Clarias gariepinus as a biomarker of organophosphate and carbamate exposure. Ecotoxicology, 19, 855-863 (2010).

Nunes, B.: The use of cholinesterase in ecotoxicology. Environ Contamina. Toxicol., 212, 29-59 (2011).

Okareh, O.T. and F. Akande: Lead and cadmium levels of African catfish (Clarias gariepinus) and the effect of cooking methods on their concentrations. Br. J. Appl. Sci. Technol., 11, 1-12 (2015).

Padrilah, S.N., S.A. Ahmad, N.A. Yasid, M.K. Sabullah, H.M. Daud, A. Khalid and M.Y. Shukor: Toxic effects of copper on liver and cholinesterase of Clarias gariepinus. Environ. Sci. Pollut. Res. Int., 24, 22510-22523 (2017).

Patnaik, B.B., H.J. Howrelia, T. Mathews and M. Selvanayagam: Histopathology of gill, liver, muscle and brain of Cyprinus carpio communis $L$. exposed to sublethal concentration of lead and cadmium. Afr. J. Biotechnol., 10, 12218-12223 (2011).

Rajkowska, M. and M. Protasowicki: Distribution of selected metals in bottom sediments of lakes lńsko and Wiola (Poland). Ecol. Chem. Engineer., 18, 805-812 (2011)

Ramudu, K.R. and G. Dash: Histopathological alterations in the vital organs of Indian major carps with parasitic infestation in fish farms 
West Bengal, India. Drug Dev. Ther., 6, 38-43 (2015).

Rani, S., R.K. Gupta and R. Manju: Heavy metal induced toxicity in fish with special reference to zinc and cadmium. Int. J. Fish. Aqua., 3 118-123 (2015).

Rodrigues, S.R., C. Caldeira, B.B. Castro, F. Gonçalves, B. Nunes and S.C. Antunes: Cholinesterase (ChE) inhibition in pumpkin seed (Lepomis gibbosus) as environmental biomarker: ChE characterization and potential neurotoxic effects of xenobiotics. Pestic. Biochem. Physiol., 99, 181-188 (2011).

Sabullah, M.K., M.R. Sulaiman, M.Y.A. Shukor, M.A. Syed, N.A. Shamaan, A. Khalid and S.A. Ahmad: The assessment of cholinesterase from the liver of Puntius javanicus as detection of metal ions. Sc. World J., 3, 1-9 (2014).

Sabullah, M.K., M.Y.A. Shukor, N.A. Shamaan, A. Khalid, A.J. Gansau, M.R. Sulaiman, H. Jirangon and S.A. Ahmad: Purification and anticholinesterase sensitivity of cholinesterase extracted from liver tissue of Puntius javanicus. Int. J. Agric. Biol., 17, 1025-1030 (2015a).

Sabullah, M.K., S.A. Ahmad, M.Y. Shukor, A.J. Gansau, M.A. Syed, M.R. Sulaiman and N.A. Shamaan: Heavy metal biomarker: Fish behavior, cellular alteration, enzymatic reaction and proteomics approaches. Int. J. Food Res., 22, 435-454 (2015b).

Saleh, Y.S. and M.A.S. Marie: Assessment of metal contamination in water, sediment, and tissues of Arius thalassinus fish from the Red Sea coast of Yemen and the potential human risk assessment. Environ. Sci. Pollut. Res., 22, 5481-90 (2014).

Sarkarati, B., A.N. Çokuğraş and E.F. Tezcan: Inhibition kinetics of human serum butyrylcholinesterase by $\mathrm{Cd}^{2+}, \mathrm{Zn}^{2+}$ and $\mathrm{Al}^{3+}$ : Comparison of the effects of metal ions on cholinesterases. Comp. Biochem. Physiol. C. Pharmacol. Toxicol. Endocrinol., 122, 181-190 (1999).

Sharbidre, A.A. and P.S. Patode: Behavioural changes and acetylcholinesterase activity in guppy fish (Poecilia reticulata) exposed to chlorpyrifos. Nat. Env. Poll. Tech., 11, 487- 492 (2012).

Sharif, M.S.A., M.I.E. Halmi, A. Syahir, W.L.W. Johari and M.Y. Shukor: Assessment of acetylcholinesterase from Channa micropeltes as a source of enzyme for insecticides detection. Int. J. Agri. Biol., 16, 389-394 (2014).

Sharma, B., S. Shweta and J.S. Nikhat: Biomedical implications of heavy metals induced imbalances in redox systems. BioMed. Res. Int., (2014). doi:10.1155/2014/640754

Shazili, M., Y. Kamaruzaman, S.A. Ahmad, A. Norantonina and A.R. Mohd Kamil: Heavy metal pollution status in the Malaysian aquatic environment. Aquat. Toxicol., 9, 137-145 (2006).

Shukor, M.S. and M.R. Sulaiman: Assessment of acetylcholinesterase (AChE) from silver catfish (Pangasius sp.) as an assay for organophosphates and carbamates. Biosci. Biotechnol. Biochem., 10, 213-218 (2013).

Silva, J.M., F.L.B. Santos, H.A. Tenório, H.J.V. Pereira, J.G. Costa, A.E.G. Santana and S.S. Machado: In vivo and in vitro inhibition of cholinesterase activity in Colossoma macropomum (tambaqui) fingerlings by the herbicide trifluralin. Ecotoxicol. Environ. Saf., 10, 23-30 (2015).

Tripathi, A. and U.C. Srivastava: Acetylcholinesterase: A versatile enzyme of nervous system. Ann. Neurosciences, 15, 106-111 (2008).

Tsim, K. and H. Soreq: Acetylcholinesterase: Old questions and new developments. Front. Mol. Neurosci., 5,101-101 (2012).

Wang, B. and Y. Du: Cadmium and its neurotoxic effects. Oxida. Med. Cell. Longe., Vol. 2013, Article ID 898034 (2013).

Zaki, M.S., A. Zakaria, I.A.E.M. Eissa and A.I.N. Eldeen: Effect of cadmium toxicity on vertebrates. Electron. Physician, 8, 19641965 (2016). 